Acta Agroph., 2019, 26(1), 79-92

doi: $10.31545 /$ aagr/110045

\title{
WATER TABLE AS A SOURCE FOR IRRIGATION IN THE NILE DELTA SOILS
}

\author{
Abdelmonem Mohamed Ahmed Amer D \\ Department of Soil Science, Faculty of Agriculture, Menoufia University \\ 32511 Shebin El-Kom, Egypt \\ e-mail: amer_abdel@hotmail.com
}

\begin{abstract}
The purpose of this study is to predict the contribution of the water table in moistening the root zone using theoretical and empirical equations containing the parameters of evapotranspiration, crop factor, and capillary rise in relation to the hydrophysical properties of soil. Five alluvial (clay) soil profiles located at middle Nile Delta were investigated for the application of the assumed equations. Four areas of soils were cultivated with wheat and clover in the winter and maize in the summer, and citrus trees in 2014/2015 growing season. Soil samples from the investigated areas were subjected to chemical and physical analyses. Water table depths were determined using field piezometers in the same places where the soil samples were collected. The other hydro-physical parameters were estimated. It was found that the water table contributed $20-40 \%$ of the irrigation water applied to the root zone in winter and $20 \%$ or less during the summer in the studied soils areas. An equation was derived to estimate the sorptivity (S) under dry conditions and at steady state infiltration. It was observed that $S$ is decreased from unsaturated state to steady-state infiltration by 23.1 to $45.7 \%$ in cultivated soils and to $55.2 \%$ in uncultivated soil. Infiltration functions were estimated. It was suggested that the sorptivity at the steady infiltration rate (steady sorptivity, $\mathrm{S}_{\mathrm{w}}$ ) may be used to predict the hydraulic conductivity and the basic infiltration rate $I_{b}$. The calculated values of $I_{b}$ by $\mathrm{S}_{\mathrm{w}}$ corresponded to those obtained by infiltration experiment. This confirmed the significance of steady $S_{w}$ as a new functional infiltration parameter. Also, data showed that the values of $K(\theta)$ calculated by the proposed equations were in the common ranges for such soils. The equations used (models) related $K(\theta)$ to soil pore radius (r) which were in turn based on soil hydraulic data including water retention $h(\theta)$, field basic infiltration rate, water sorptivity $(S)$ and the distribution density function $f(r)$ of soil pore size. The steady $\mathrm{S}_{\mathrm{w}}$ parameter was used in the prediction of the hydraulic conductivity $K(\theta)$ and the basic (steady) infiltration rate $I_{b}$. It was concluded that in winter the water table contributed $20-40 \%$ of irrigation water applied to the root zone and less than $20 \%$ during the summer in the studied soils areas. These values should be considered in calculating the crop water requirements.

Keywords: Infiltration functions, water table, moistening of the root zone, steady sorptivity, hydraulic conductivity, capillary rise
\end{abstract}




\section{INTRODUCTION}

The interaction between ground water and surface water is an integral part of the hydrological cycle (Fig. 1). The infiltration, evaporation, and transpiration processes are the most interesting ones for agricultural purposes. Infiltration is the passage of water into the soil surface and may be distinguished from percolation, which is the movement of water through the soil profile.

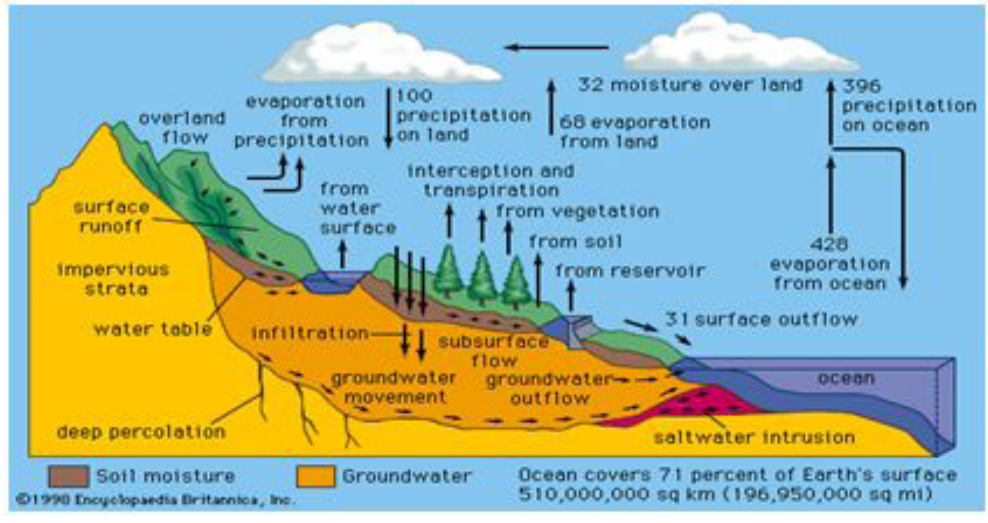

Fig. 1. The hydrological cycle (Encyclopedia, 1998)

A knowledge of the hydraulic properties of soil in relation to water infiltration is essential in order to quantify the rate of water flow and transport processes in the plant root zone. Water flows in the root zone occur principally through the macro non-capillary pores of the soil, while redistribution and upward flows occur in the capillary soil matrix pores. The water conductivity of soil pores is mainly determined by pore sizes, continuity and pore size distribution in the soil. The unsaturated hydraulic conductivity $K(\theta)$ and the relationships between water content $(\theta)$, pressure head $(h)$ and soil pore size are important for quantifying the rate of water flow and transport through the vadose zone. Water moves into soil pores due to gradients in water content and potentials, and this movement usually occurs from a wet soil to a dry one. The rise of water in the soil from a free-water surface often contributes to the process of evaporation in the presence of a high-water table.

The purpose of this work is: (1) to predict the contribution of the water table in moistening the root zone of Nile Delta soils, (2) to use the proposed equations in estimating infiltration functions, and hydraulic conductivity [saturated, Ks and unsaturated, $K(\theta)$ ], and (3) to predict water sorptivity $(\mathrm{Sw})$ at steady state infiltration. 


\section{Pore size classes}

Water is held in soil pores by cohesive and adhesive capillary forces. The size of pores in the unsaturated soil state may be determined from the hydraulic radius $(r)$ of a section of pore space. The relationship between the equivalent (cylindrical) pore size radius $(r)$ and capillary forces expressed as the pressure head potential (h) per length unit $[\mathrm{L}]$ or water potential $(\psi)\left[\mathrm{M} \mathrm{L} \mathrm{T}^{-2}\right]$ where $\Psi=\rho_{w} g h$, may be estimated using the capillary rise equation (Hillel, 1980):

$$
h=\frac{2 \gamma \cos \alpha}{g r \rho_{w}}
$$

where, $\gamma$ is the surface tension between water and air $\left(\right.$ at $\left.20^{\circ} \mathrm{C}=0.0727 \mathrm{~kg} \mathrm{~s}^{-2}\right), \cos \alpha$ is assumed to be 1 for a wet surface, $g$ is acceleration due to gravity $\left(9.8 \mathrm{~m} \mathrm{~s}^{-2}\right)$, and $\rho_{w}$ is the density of water $\left(998 \mathrm{~kg} \mathrm{~m}^{-3}\right.$ at $\left.20^{\circ} \mathrm{C}\right)$.

Pore size classes were determined from soil water retention curves (Amer, 2002 ) by applying equation (1). The equivalent pressure $(h)$ ranges $\Psi=0-10,10-33$, $10-1500,33-1500$, and $>1500 \mathrm{kPa}$, roughly correspond to the diameters of rapid draining pores $(R D P)$, slowly draining pores $(S D P)$, coarse capillary pores $(C C P)$, water-holding pores $(W H P)$ (or the available water), and fine capillary pores $(F C P)$ respectively. The cutoff equivalents $r$ for water potentials; $\Psi=10,33$, and 1500 $\mathrm{kPa}$ are $14.47,4.36$, and $0.099 \mu \mathrm{m}$ respectively. The pressure head $h=100 \mathrm{hPa}$ was selected as it corresponds to the limit between the capillary and non-capillary pores (Amer et al. 2009).

\section{Hydraulic conductivity and water flow}

The unsaturated state of soil water is a major phenomenon in nature after irrigation or rainfall. As soil dries out, increasing suction occurs due to the progressive emptying of capillary pores. The effects of the unsaturated flow of water on minimizing the moisture gradients within the root zone are worthy of further investigation.

If soil pores are modelled by strait, cylindrical capillary pores, then Poiseuille's equation for water flow or discharge rate $(q)\left[\mathrm{L}^{3} \mathrm{~T}^{-1}\right]$ through one capillary tube may be applied. Amer (2012) introduced the following equation to predict $q$ in soil pores;

$$
q=\frac{\pi r^{2} \rho_{w} g r^{2} \sum_{W a}^{R D P} \frac{\Delta \theta}{\theta_{S}}}{8 \eta T} \frac{\Delta h}{\Delta L}
$$

where, $\Delta h / \Delta L$ is the total hydraulic gradient (it was set to 1 ), and the cross-sectional area, $\pi r^{2}$ was for the largest $r$ of the class, $\eta$ is water viscosity $\left(0.001 \mathrm{~kg} \mathrm{~m}^{-1} \mathrm{~s}^{-1}\right.$ at $20^{\circ} \mathrm{C}$ ), $\mathrm{Wa}$ is the water adsorption capacity, $\Delta \theta$ is the volume fraction of pores occupied by water and $\pi r^{2}$ is the cross-sectional area of one equivalent cylindrical pore. $\Delta \theta$ can be expressed as the ratio of soil bulk volume $\left(\mathrm{m}^{3} \mathrm{~m}^{-3}\right)$ or of the total volume 
of the pores $(\Delta \theta / \theta s)$ where $\theta_{\mathrm{s}}$ is the saturated water content. Quantifying the unsaturated water flow into the soil pores requires knowledge of hydraulic conductivity $K(\theta)$ and soil water retention $h(\theta)$ or $\psi(\theta)$ (Dane and Topp 2002).

In the directions of $\mathrm{x}, \mathrm{y}$, and $\mathrm{z}$ among long tortuous pathways of different pore sizes, the unsaturated hydraulic conductivity, $K(\theta)$ differs by orders of magnitude due to very small changes in soil porosity and in water potential as well as in the degree of saturation $\left(\theta_{\mathrm{i}} / \theta_{\mathrm{s}}\right)$. In that case $\mathrm{K}(\theta)$ values for any pore size class will be reduced by 200 fold (Sudnitcyn, 1979), and at a certain water content $\theta i$ :

$$
K(\theta)_{i}=\frac{\rho_{w} g r^{2}}{8 \eta T} \frac{\Delta \theta_{i}}{\theta_{S}}
$$

where $T=$ tortuous pathways factor $(T=200)$ and $\Delta \theta_{i}$ is the soil moisture content at a certain pore size class $(i)$.It was found that in narrow capillaries, the flux is smaller than that which is predicted by Poiseuille's equation for viscous flow (Ravina and Zaslavsky 1968). Therefore Eq. 3 should be adjusted by adding a matching factor $\left(=K_{s} / K_{c}\right)$ or the ratio of the measured saturated $K_{S}$ to that calculated at $\Delta \theta<1 \mathrm{kPa}$ for $r \geq 0.15 \mathrm{~mm}$, especially for large, non-capillary pores, i.e. $K_{c}=\sum_{W a}^{R D P} K(\theta)$ where $W_{a}$ is an immobile soil-adsorbed water capacity. Then Eq. 3 becomes:

$$
K(\theta)_{i}=\frac{K_{S}}{K_{C}} \frac{\rho_{w} g r^{2}}{8 \eta T} \frac{\Delta \theta_{i}}{\theta_{S}}
$$

The pore radius was assumed to be the largest for the class because the data was cumulated starting at the dry end and the largest radius of the smaller class is the smallest boundary for the next larger class. The $<10 \mathrm{kPa}$ class (RDP) was calculated as the mean of the $0.1-10 \mathrm{kPa}$ class. The unsaturated hydraulic conductivity, $\mathrm{K}(\theta)$ of the soil pores is divided into $\mathrm{K}(\theta)_{\mathrm{RDP}}, \mathrm{K}(\theta)_{\mathrm{SDP}}, \mathrm{K}(\theta)_{\mathrm{WHP}}$, and $\mathrm{K}(\theta)_{\mathrm{FCP}}$ within the rapidly drainable pores, RDP refers to for the slowly drainable pores, SDP refers to for the water-holding pores (WHP) and FCP refers to fine capillary pores, respectively.

\section{Infiltration and steady sorptivity, $S_{w}$}

For many soils, a plot of cumulative infiltration $\mathrm{Z}$ [L] as a function of time $\mathrm{t}[\mathrm{T}]$ is described by the equation (Kostiakov 1932):

$$
Z=c t^{m}
$$

where, $c\left[\mathrm{LT}^{-\mathrm{m}}\right]$ and $m$ [dimensionless] are empirical coefficients for a given soil and a given moisture content, respectively. By differentiating the expression for $\mathrm{Z}$ (Eq. 5) with respect to time $\mathrm{t}$, the infiltration rate (instantaneous) $\mathrm{I}\left[\mathrm{LT}^{-1}\right]$ at the soil surface is defined as: 


$$
I=\frac{d Z}{d t}=c m t^{m-1}
$$

At steady-state infiltration, the infiltration rate, $I$, becomes constant and is denoted as the basic (final) infiltration rate, $\mathrm{I}_{\mathrm{b}}$. The time $(\mathrm{t}, \mathrm{hr})$ that must elapse before the instantaneous infiltration rate, I, becomes approximately constant can be expressed in terms of the $m$ coefficient (Amer,2012);

$$
t=10(1-m) \text { and } \sqrt{t}=[10(1-m)]^{0.5}
$$

Valiantzas et al. (2009) pointed out that the variation in soil initial water content affected the value of sorptivity, $\mathrm{S}$, whereas $\mathrm{S}\left[\mathrm{LT}^{-1 / 2}\right]$ was originally defined by the Philip (1957) equation for horizontal infiltration into an initially dry soil. Amer (2012) concluded that sorptivity, $\mathrm{S}\left[\mathrm{LT}^{-0.5}\right]$ at unit time may be applied to calculate $I_{b}$ as well as $K(\theta)_{i}$ when $I_{b}=u K(\theta)_{\mathrm{I}}$ where $u$ is a matching factor;

$$
I_{b}=\frac{S m}{(1-m) \sqrt{t}} \text { or } K(\theta)_{i}=\frac{S m}{u(1-m) \sqrt{t}}
$$

However, the sorptivity $\mathrm{S}$ at measured steady-state infiltration $\mathrm{I}_{\mathrm{b}}$ can be defined in term steady sorptivity, $\mathrm{S}_{\mathrm{w}}$. According to Amer (2012), $S_{w}$ may be predicted using the equation;

$$
S_{w}=\mathrm{I}_{b(\text { measured })}\left(\frac{1-m}{m}\right) \sqrt{t}
$$

where the measured $\mathrm{I}_{\mathrm{b}}$ is obtained from experimental data at the time $\sqrt{t}$.

By measuring sorptivity $\left(\mathrm{S}_{\mathrm{w}}\right)$ and using it as a scaling factor, the unsaturated hydraulic conductivity $\mathrm{K}(\theta)$ can be predicted fairly accurately (Moldrup et al. 1993). The application of a one-dimensional form of Darcy's equation using the average $\mathrm{K}(\theta)$ and hydraulic gradient with reference to the steady infiltration rate may be useful in the prediction of water flow in unsaturated soils.

\section{Water table and moistening of the root zone}

The rise of water in the soil from a free-water surface (i.e., water table) has been termed capillary rise. Using Eq. (1), the capillary rise $(h)$ of water into the soil profile may be determined. Above the water table, matric suction will generally increase with height, $\mathrm{d} \Psi / \mathrm{dz}$ and hence soil wetness, also the rate of capillary rise will decrease as a function of height and time. Evaporation from the soil surface is generally unimportant at moisture levels below field capacity, as soil moisture movement is very slow when the soil is relatively dry. In this case, transpiration is more effective than evaporation. However, evaporation and transpiration are difficult to separate and are often considered together as evapotranspiration. 
The actual rate of evapotranspiration may be used to determine the contribution of shallow ground water in the irrigation of the root zone by applying the following empirical equation (Amer 2004):

$$
S r=\frac{E T_{a}}{e^{m Z}}
$$

where $\mathrm{Sr}$; capillary rise of soil water ( $\mathrm{mm} /$ day), $E T_{a}$; actual rate of evapotranspiration ( $\mathrm{mm} /$ day), $m$; crop parameter and $Z$; water table depth $(\mathrm{m})$.

The crop factor $(m)$ may be calculated using Eq.10 in a logarithmic form (Amer 2004):

$$
m=\left[\frac{\log E T a-\log S r}{0.4343 Z}\right]
$$

In order to determine the rate of evapotranspiration (ETa), the soil moisture depletion (SMD) ( $\mathrm{mm} /$ day) of the soil profiles during the growth seasons should be used (Amer 2004):

$$
S M D=\frac{\Delta P W}{100} \frac{\rho b}{\rho w} \frac{D}{I P}
$$

where: $D$ : wetted soil root depth $(\mathrm{cm})$ (soil layer thickness); $\triangle P W$ : the change in the gravimetric moisture content (\%) before and after irrigation; $I P$ : irrigation interval (period, days); $\rho b \& \rho w$ is the soil bulk density and water density respectively.

The ETa ( $\mathrm{mm} /$ day) may be calculated by applying the following water balance relationship;

$$
E T_{a}=S M D+S r
$$

where $\mathrm{Sr}$ is the capillary rise of soil ( $\mathrm{mm} /$ day).

Empirically, the evapotranspiration (ETa) rate, may be predicted through the application of the Campbell equation (1974) with Eq.10:

or

$$
E T_{a}=\frac{d \theta}{d \psi} b \cdot \psi_{e} \cdot K_{s} \frac{\theta^{b+2}}{\theta_{S}^{b+3}}\left(\frac{d \psi}{d z}-1\right) e^{m Z}
$$

$$
E T_{a}=b \cdot \psi_{e} \cdot K_{s} \frac{\theta^{b+2}}{\theta_{S}^{b+3}}\left[\frac{d \theta}{d z}-K(\psi)\right] e^{m Z}
$$

where: $\psi \mathrm{e}$ is the air entry water potential, $\Theta$ s is the saturated water content, $\Theta$ is volumetric wetness, $\mathrm{b}$ is an empirical constant, and $\mathrm{Ks}$ is the saturated hydraulic conductivity. $\mathrm{d} \Theta / \mathrm{d} \psi$ is the slope of moisture characteristic curve and $\mathrm{d} \Theta / \mathrm{dz}$ is the volumetric water content change with depth(z). 


\section{MATERIALS AND METHODS}

The experiment was carried out in season 2014-2015 in five cultivated and non-cultivated alluvial clay soils. Four cultivated areas in the Menoufia region (middle Nile Delta, Egypt) were selected in the locations of El Baghor(I), Berkat Elsaba(II), Talla(III), and Shebin ElKom(IV), while the fifth location (V) in the Ebshan, Kafr Elsheikh region (Nile Delta) was uncultivated. All of the investigated areas were located in between the two branches of the Nile Delta (Fig. 2).

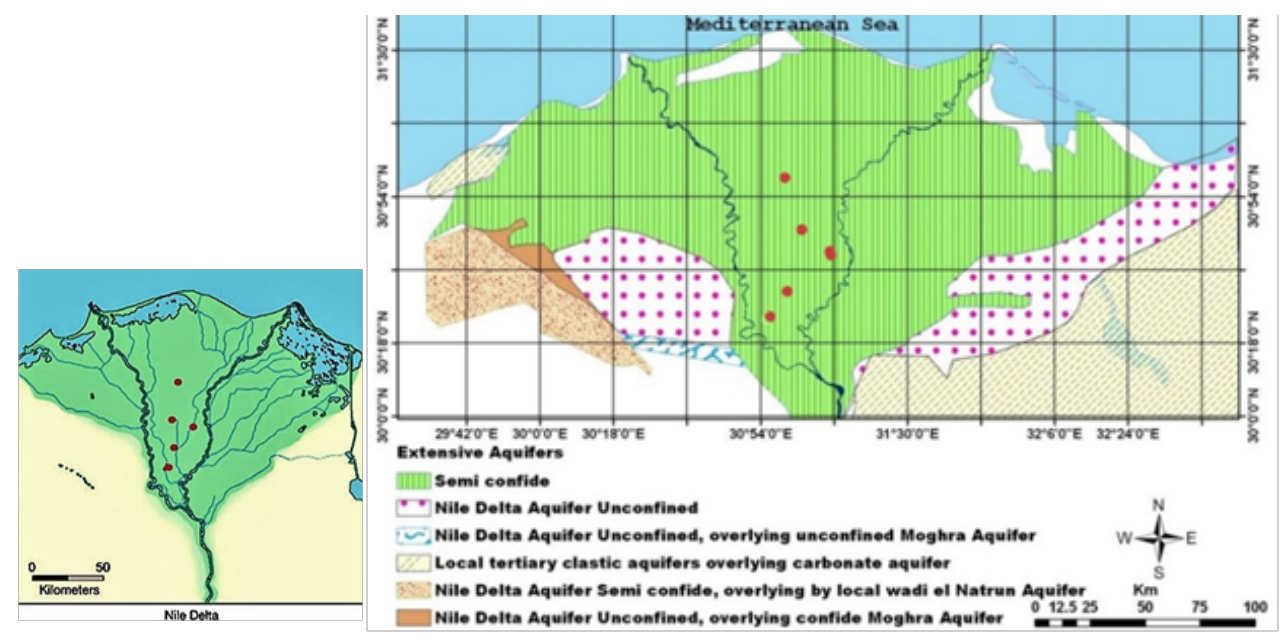

Fig. 2. Investigated soil areas in the middle Nile Delta and groundwater aquifers

The locations of El-Bghour and Shebin El-Kom areas were cultivated with wheat in the winter and with maize in the summer, the location of Berket El-Saba area was cultivated with clover in the winter and maize in the summer. Citrus trees were cultivated in the Talla area. The irrigation system used in four of the cultivated areas was furrow irrigation. The actual rate of evapotranspiration (ETa) was estimated empirically for the studied areas as; $2.35-8.17 \mathrm{~mm} \mathrm{day}^{-1}$ for the months from November, 2014 to August, 2015. Soil samples were taken from all areas at different depths. Soil samples were prepared for chemical and physical analysis (Tab. 1) according to Page (1982), Sparks et al., (1996), and Dane and Topp, (2002). The water table depths were determined using field piezometers in the same locations as the collected soil samples. The crop coefficient $(m)$ was predicted using the logarithmic form of Eq.10. Saturated hydraulic conductivity (Ks) was measured with the constant head method as discussed in Klute (1986). The $[\theta]_{0-10 \mathrm{kPa}}$ soil water content was determined on a volume basis at suction pressure head $h=10 \mathrm{kPa}$ using undisturbed samples for the investigated soils. The hydration envelopes in which the water content is considered to be immobile in the soil may be expressed as the moisture adsorption capacity ( $\mathrm{Wa})$ (Amer, 2009): 


$$
W a=W m+2 W m e
$$

where $\mathrm{Wm}$ is the mono-adsorbed layer of water molecules on soil particles, and $W m e$ is the external mono-adsorbed layer of water molecules. The water vapour adsorption isotherm method with the application of the BET theory was used to estimate $\mathrm{Wm}$ and Wme. The infiltration rate was measured using the double ring method (Ankeny 1992 and Reynolds et al. 2002) in the field for the soils under consideration. The other hydrophysical properties were determined according Vadunina and Karchagina (1973).

Table 1. Physical and chemical properties of the studied soils

\begin{tabular}{|c|c|c|c|c|c|c|c|c|c|c|}
\hline \multirow{2}{*}{$\begin{array}{c}\text { Soil } \\
\text { profile and } \\
\text { location }\end{array}$} & \multirow{2}{*}{$\begin{array}{l}\text { Soil } \\
\text { depth } \\
(\mathrm{cm})\end{array}$} & \multirow{2}{*}{$\begin{array}{l}\mathrm{EC}^{*} \\
\mathrm{dS} \mathrm{m}^{-1}\end{array}$} & \multirow[t]{2}{*}{ SAR } & \multirow{2}{*}{$\begin{array}{c}\rho_{\mathrm{b}} \\
\mathrm{g} \mathrm{cm}^{-3}\end{array}$} & \multirow{2}{*}{$\begin{array}{l}\mathrm{CaCO}_{3} \\
\%\end{array}$} & \multicolumn{3}{|c|}{$\begin{array}{c}\text { Particle size distribution } \\
\% \\
\end{array}$} & \multirow{2}{*}{$\begin{array}{l}\text { Texture } \\
\text { class }\end{array}$} & \multirow{2}{*}{$\begin{array}{c}\theta_{\mathrm{s}} \\
\mathrm{m}^{3} \mathrm{~m}^{-3}\end{array}$} \\
\hline & & & & & & Sand & Silt & Clay & & \\
\hline \multirow{3}{*}{$\begin{array}{l}\mathrm{P}(\mathrm{I}) \\
\text { El-Bagour }\end{array}$} & $0-30$ & 1.10 & 2.17 & 1.32 & 0.43 & 17.40 & 42.78 & 39.82 & S.C.L & 0.4962 \\
\hline & $30-60$ & 1.61 & 3.09 & 1.34 & 1.37 & 12.26 & 40.36 & 47.48 & S.C & 0.5806 \\
\hline & $60-90$ & 0.66 & 3.38 & 1.37 & 1.39 & 13.38 & 32.12 & 54.50 & clay & 0.6210 \\
\hline P(II) & $0-30$ & 1.88 & 3.93 & 1.36 & 2.10 & 21.80 & 35.34 & 42.86 & clay & 0.5106 \\
\hline Berket & $30-60$ & 3.34 & 6.24 & 1.39 & 1.33 & 20.91 & 32.85 & 46.24 & clay & 0.5594 \\
\hline Elsaba & $60-90$ & 3.77 & 5.41 & 1.42 & 1.77 & 16.36 & 32.45 & 51.19 & clay & 0.5938 \\
\hline \multirow{3}{*}{$\begin{array}{l}\mathrm{P}(\mathrm{III}) \\
\text { Talla }\end{array}$} & $0-30$ & 1.49 & 2.27 & 1.17 & 2.31 & 15.78 & 32.48 & 51.74 & clay & 64.29 \\
\hline & $30-60$ & 1.53 & 2.81 & 1.22 & 2.40 & 19.16 & 27.10 & 53.74 & clay & 0.6100 \\
\hline & $60-90$ & 1.65 & 2.24 & 1.25 & 2.70 & 22.10 & 29.72 & 48.18 & clay & 0.6078 \\
\hline P(IV) & $0-30$ & 1.90 & 3.79 & 1.30 & 2.10 & 23.76 & 35.28 & 40.96 & Clay & 0.6577 \\
\hline Shebin & $30-60$ & 1.60 & 4.73 & 1.38 & 1.84 & 23.60 & 34.75 & 41.65 & Clay & 0.6931 \\
\hline El-Kom & $60-90$ & 2.00 & 9.90 & 1.35 & 0.92 & 22.29 & 32.91 & 44.80 & Clay & 0.6628 \\
\hline \multirow{3}{*}{$\begin{array}{l}\mathrm{P}(\mathrm{V}) \\
\text { Ebshan }\end{array}$} & $0-30$ & 2.30 & 6.48 & 1.27 & 0.84 & 21.98 & 15.37 & 62.65 & Clay & 0.7212 \\
\hline & $30-60$ & 1.89 & 4.75 & 1.28 & 0.98 & 14.31 & 18.69 & 67.00 & Clay & 0.7684 \\
\hline & $60-90$ & 1.22 & 3.11 & 1.28 & 0.79 & 16.44 & 24.38 & 59.18 & Clay & 0.7325 \\
\hline
\end{tabular}

*EC is electrical conductivity, SAR is the sodium adsorption ratio, $\rho_{\mathrm{b}}$ is bulk density, S.C.L is silty clay loam, S.C is silty clay and $\theta_{\mathrm{s}}$ is the saturation water content

\section{RESULTS AND DISCUSSION}

\section{Sorptivity and hydraulic conductivity}

Data concerning the infiltration parameters and water sorptivity are given in Table 2. The typical trends in cumulative infiltration, $Z(\mathrm{~cm})$ versus time $t$ (minutes) and infiltration rate, $I\left(\mathrm{~cm} \mathrm{~h}^{-1}\right)$ are illustrated by empirical power functions ( 5 and 6) according to Kostiakov, 1932. The constants $c$ and $m$ of the equations are calculated for the investigated soil profiles. With the onset of wetting, the moisture 
gradient was at its height, hence a more rapid infiltration was obtained. The infiltration rate, $I\left(\mathrm{LT}^{-1}\right)$ slowed gradually with time $\mathrm{t}$ and reached an infiltration rate with a steady state, $\left(I_{b}\right)$ after 4.6-5.4 hr from the beginning of infiltration.

Table 2. Infiltration functions, water sorptivity and hydraulic conductivity of the studied soils.

\begin{tabular}{|c|c|c|c|c|c|c|c|c|c|}
\hline $\begin{array}{l}\text { Soil profile } \\
\text { and location }\end{array}$ & $\begin{array}{c}\text { Soil } \\
\text { depth } \\
(\mathrm{cm})\end{array}$ & $\begin{array}{l}\mathrm{Z}, \mathrm{cm} \& \\
\mathrm{I}, \mathrm{cm} / \mathrm{h}\end{array}$ & $\begin{array}{c}\mathrm{S} \\
\mathrm{cm} / \mathrm{min}^{0.5}\end{array}$ & $\underset{5}{\stackrel{S_{w}}{\mathrm{~cm} / \mathrm{min}^{0.5}}}$ & 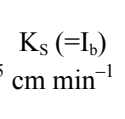 & 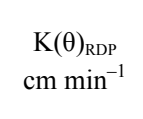 & $\begin{array}{c}{ }^{*} \mathrm{Ks} \\
\mathrm{cm} \mathrm{h}^{-1}\end{array}$ & $\begin{array}{c}(\mathrm{u}) \\
\mathrm{I}_{\mathrm{b}} /{ }^{*} \mathrm{~K}_{\mathrm{s}}\end{array}$ & $\begin{array}{r}{[\theta]_{0-10 k P a}} \\
\mathrm{~m}^{3} \mathrm{~m}^{-3}\end{array}$ \\
\hline $\mathrm{I}$ & $0-30$ & $74 \mathrm{~T}^{0.54}$ & \multirow[b]{2}{*}{0.713} & \multirow[b]{2}{*}{0.548} & \multirow[b]{2}{*}{0.041} & $7.38 \times 10^{-4}$ & 2.80 & 0.879 & 0.0544 \\
\hline El-Bagour & $\begin{array}{l}30-60 \\
60-90\end{array}$ & $\begin{array}{l}Z=0.14 \mathrm{I}^{-0.46} \\
\mathrm{I}=23.9 \mathrm{~T}^{-0.46}\end{array}$ & & & & $6.89 \times 10^{-4}$ & 2.55 & 0.965 & 0.0428 \\
\hline II & $\begin{array}{c}00-90 \\
0-30\end{array}$ & \multirow{3}{*}{$\begin{array}{l}\mathrm{Z}=0.70 \mathrm{~T}^{0.53} \\
\mathrm{I}=22.2 \mathrm{~T}^{-0.47}\end{array}$} & \multirow{3}{*}{0.706} & \multirow{3}{*}{0.463} & \multirow{3}{*}{0.038} & $\begin{array}{l}6.61 \times 10 \\
7.30 \times 10^{-4}\end{array}$ & $\begin{array}{l}2.46 \\
2.40\end{array}$ & $\begin{array}{l}1.000 \\
0.950\end{array}$ & $\begin{array}{l}0.0318 \\
0.0414\end{array}$ \\
\hline Berket & $30-60$ & & & & & $6.59 \times 10^{-4}$ & 2.35 & 0.970 & 0.0412 \\
\hline Elsaba & $60-90$ & & & & & $5.72 \times 10^{-4}$ & 2.290 & 0.995 & 0.0347 \\
\hline & $0-30$ & & \multirow[b]{2}{*}{0.588} & \multirow[b]{2}{*}{0.395} & \multirow[b]{2}{*}{0.034} & $6.59 \times 10^{-4}$ & 2.68 & 0.761 & 0.0366 \\
\hline Talla & $30-60$ & $\mathrm{I}=14.6 \mathrm{~T}^{-0.48}$ & & & & $5.66 \times 10^{-4}$ & 2.50 & 0.816 & 0.0369 \\
\hline \multirow{3}{*}{$\begin{array}{l}\text { IV } \\
\text { Shebin } \\
\text { El-Kom }\end{array}$} & $0-30$ & & \multirow{3}{*}{0.627} & \multirow{3}{*}{0.340} & \multirow{3}{*}{0.023} & $\begin{array}{l}4.09 \times 10 \\
8.75 \times 10^{-4}\end{array}$ & $\begin{array}{l}2.01 \\
2.20\end{array}$ & $\begin{array}{l}0.985 \\
0.623\end{array}$ & $\begin{array}{l}0.0343 \\
0.0252\end{array}$ \\
\hline & $30-60$ & $\mathrm{Z}=0.61 \mathrm{~T}^{0.53}$ & & & & $8.16 \times 10^{4}$ & 1.78 & 0.769 & 0.0248 \\
\hline & $60-90$ & $\mathrm{I}=19.3 \mathrm{~T}^{-0.47}$ & & & & $1.02 \times 10^{-4}$ & 1.72 & 0.796 & 0.0297 \\
\hline V Ebshan & $\begin{array}{c}0-30 \\
30-60 \\
60-90\end{array}$ & $\begin{array}{l}Z=0.59 T^{0.46} \\
I=16.4 T^{-0.54}\end{array}$ & 0.574 & 0.257 & 0.012 & $\begin{array}{l}3.71 \times 10^{-4} \\
3.12 \times 10^{-4} \\
3.30 \times 10^{-4}\end{array}$ & $\begin{array}{l}1.25 \\
1.04 \\
1.13\end{array}$ & $\begin{array}{l}0.584 \\
0.702 \\
0.646\end{array}$ & $\begin{array}{l}0.0221 \\
0.0198 \\
0.0200 \\
\end{array}$ \\
\hline
\end{tabular}

$[\theta]_{0-10 \mathrm{kPa}}$ is drained water of macro pores, and ${ }^{*} \mathrm{Ks}$ measured saturated hydraulic conductivity

Hallett (2008) mentioned that sorptivity is the capacity of soil to absorb (suck up) water and is dominated by the antecedent water content of the soil. At the beginning of infiltration in an initially dry soil (un-saturated conditions), the sorptivity, $\mathrm{S}$ may be calculated using $Z$ as a function of time $t$ and adjusted to $m=0.5$. The $\mathrm{S}$ values were found to range from 0.574 to $0.713 \mathrm{~cm} / \mathrm{min}^{0.5}$ in all studied soils (Tab. 2).

Sorptivity (S) at steady-state infiltration was denoted as steady sorptivity $\left(\mathrm{S}_{\mathrm{W}}\right)$ and calculated using Eq. 9. It worth noting that the data of the infiltration rate at steady-state infiltration $I_{b}$, which was calculated via steady sorptivity $\left(\mathrm{S}_{\mathrm{w}}\right)$ corresponded to those obtained using the experimental data. This confirm the significance of $\mathrm{S}_{\mathrm{W}}$ in predicting the hydrological soil parameters such as $I_{b}, K s$ and $K(\theta)_{i}$. It was observed that sorptivity decreased at steady-state infiltration by $45.8-61.9 \%$ in the investigated soils. This means that a dry soil typically has a much greater sorptivity than a wet soil (Hallett, 2008). These results were attributed to soil texture, and the chemical and physical composition of clay soils. The data presented in Table 2 shows the calculated and measured saturated hydraulic conductivity, Ks, and the values of the unsaturated hydraulic conductivity $\mathrm{K}(\theta)$ as calculated by the derived equations for the macropores (RDP) of the investigated soils. (Amer, 2010, 2011 and Weiler, 2017). The values of Ks and $K(\theta)_{R D P}$ remained higher in both locations (El-Bagour (I) and Shebin El-Kom (IV)) and lower in Ebshan-location V. This is 
due to the heavy clay texture of the Ebshan soil (profile V). The $K(\theta)_{R D P}$ values for various soil areas were as follows; Shebin El-Kom (IV) $>$ El Baghor (I) $>$ Berkat ElSaba (II) > Talla (III) > Ebshan (V). The values of the saturated hydraulic conductivity, Ks, were higher in profile IV than in profile V, where it occurred in the following order; El Baghor (I) > Talla (III) > Berkat ElSaba (II) > Shebin El-Kom $(\mathrm{IV})>$ Ebshan $(\mathrm{V})$. Ks increased with increases in pore sizes, soil porosity, and water content; $\theta$ and $[\theta]_{0-10 k P a}$ (Germann and Prasuhn, 2018). On the other hand, the Ks values are also influenced by the prevailing fine clay fraction, salinity, fine and coarse capillary pores, and the steady infiltration rate in the soil matrix of such clay soils. A matching factor $u$ was calculated as the ratio between the predicted $I_{\mathrm{b}}$ (Eq. 8) and the measured Ks (Tab. 2). The mean values of $u$ were $0.95,0.97,0.85$, $0.73,0.64$ in I, II, III, IV\&V soil areas respectively. Due to the opposing trend between Ks and the clay fraction, the matching factor increased with increasing clay fraction in the soil profile.

\section{Capillary rise and water table as it contributes to root zone irrigation:}

The capillary rise rate ( $\mathrm{Sr}, \mathrm{mm} /$ day) in the studied soil profiles was calculated using Eq. 1. It was found that the soil capillary rise $(\mathrm{Sr})$ values were calibrated to between 1.15 to $1.61 \mathrm{~cm} /$ day for all the studied clay areas. The mean values for the studied soils were 1.31, 1.43, 1.47, and $1.26 \mathrm{~cm} /$ day for El-Baghour, Berket El-Saba, Talla and Shibien El-Kom soil profiles respectively. The capillary rise depends on the depth of the water table and the suction at the soil surface, the hydraulic gradient along the soil depth, water adsorption capacity, soil texture, porosity, pore size distribution and capillary tortuosity. The obtained results are in agreement with those obtained by Malik et al. (1989), Jorenush and Sepaskhah (2003), Lu and Likos (2004) and Baehr and Reilly (2014).

Measurements of water table levels $(Z)$ for the soils of the Nile Delta during the growth period of wheat, clover, maize and citrus were performed using the piezometers method in the field. The piezometers were sited midway between drains and recorded data before and after direct irrigation (on one day). The obtained data showed that the depth of the water table before irrigation was deeper in summer (May - August) for soils cultivated with a maize crop, while the depth of the water table was lower in the winter season for wheat and clover cultivated soils (Table 3 ). The highest values before irrigation through season 2014-2015 were 135, 139, 123 and $136 \mathrm{~cm}$ for El-Bghour, Berket El-Saba, Talla and Shibien El-Kom soil areas, respectively, while the lowest values were $111,110,89$ and $91 \mathrm{~cm}$ in the same soils. This may be attributed to the higher volume of water evapotranspiration during the summer season than that of the winter season, which has more precipitation. Also, soil evaporation is related to the exfiltration process associated with capillary rise 
from the water table, and to the particle size and moisture content of the soil. Data in Table 3 also shows the values of crop factor $(m)$ as calculated by equation (11). The $m$ values are calibrated between $0.66-1.74$ for all soils under consideration.

Table 3. Water table levels $(\mathrm{Z}, \mathrm{cm})$ and crop factor $(\mathrm{m})$ for the studied areas cultivated with wheat, clover, maize and citrus trees during season 2014-2015

\begin{tabular}{|c|c|c|c|c|c|c|c|c|c|c|}
\hline \multirow{2}{*}{\multicolumn{2}{|c|}{ Crop }} & \multirow{2}{*}{ 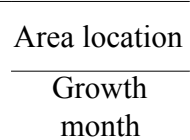 } & \multicolumn{2}{|c|}{$\begin{array}{l}\text { El-Baghour } \\
(\mathrm{P} 1)\end{array}$} & \multicolumn{2}{|c|}{$\begin{array}{c}\text { Berket } \\
\text { El-Saba }(\mathrm{P} 2)\end{array}$} & \multicolumn{2}{|c|}{ Talla (P3) } & \multicolumn{2}{|c|}{$\begin{array}{c}\text { Shebin } \\
\text { El-Kom (P4) }\end{array}$} \\
\hline & & & Z & $\mathrm{m}$ & Z & $\mathrm{m}$ & Z & $\mathrm{m}$ & Z & $\mathrm{m}$ \\
\hline \multirow{10}{*}{$\begin{array}{l}\text { Citrus } \\
\text { trees } \\
\text { (P3) }\end{array}$} & \multirow{5}{*}{$\begin{array}{l}\text { Wheat } \\
\text { (P1, P4 } \\
\text { Clover } \\
\text { (P2) }\end{array}$} & November & 116 & 1.14 & 120 & 1.24 & 89 & 0.66 & 96 & 0.86 \\
\hline & & December & 111 & 1.25 & 113 & 1.21 & 92 & 0.78 & 91 & 0.92 \\
\hline & & January & 118 & 1.49 & 115 & 1.46 & 100 & 1.21 & 99 & 1.23 \\
\hline & & February & 122 & 1.59 & 110 & 1.42 & 97 & 1.17 & 103 & 1.25 \\
\hline & & March & 127 & 1.67 & 125 & 1.66 & 107 & 1.30 & 115 & 1.66 \\
\hline & \multirow{3}{*}{$\begin{array}{l}\text { Maize } \\
(\mathrm{P} 1, \mathrm{P} 2,\end{array}$} & April & 126 & 1.72 & 124 & 1.62 & 105 & 1.17 & 117 & 1.44 \\
\hline & & May & 135 & 1.76 & 132 & 1.53 & 116 & 1.19 & 124 & 1.36 \\
\hline & & June & 128 & 1.73 & 137 & 1.56 & 123 & 1.18 & 129 & 1.37 \\
\hline & \multirow[t]{2}{*}{ P4) } & July & 127 & 1.63 & 139 & 1.62 & 120 & 1.30 & 130 & 1.39 \\
\hline & & August & 135 & 1.74 & 133 & 1.29 & 116 & 1.25 & 136 & 1.42 \\
\hline
\end{tabular}

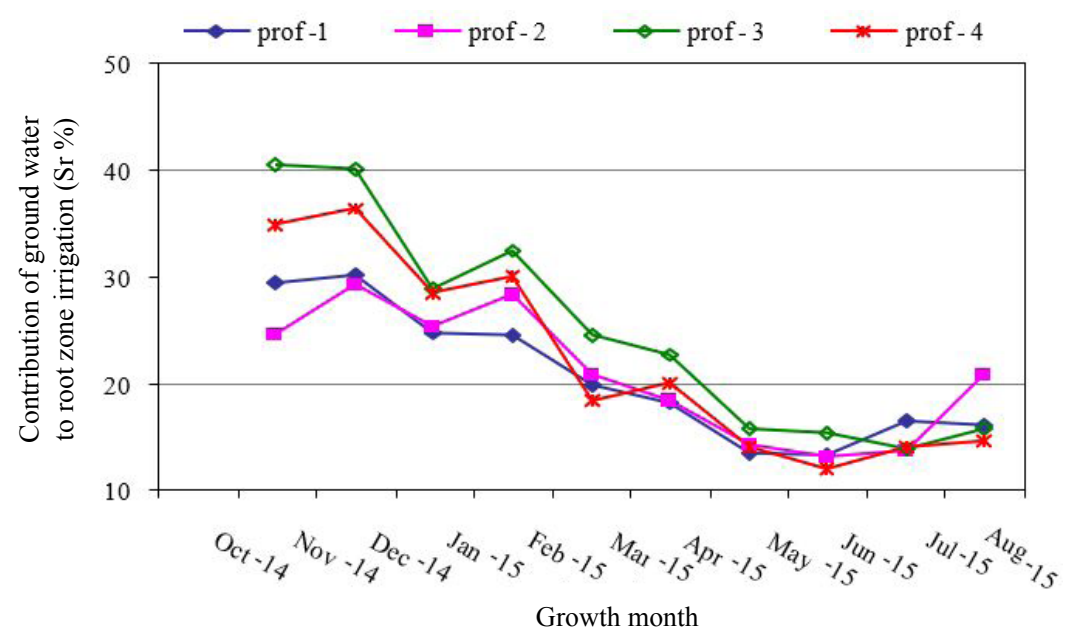

Fig. 3. Contribution of the water table to root zone irrigation ( $\mathrm{Sr} \%$ ) during the 2014-2015 season in the studied Nile Delta soils

By applying Eq. 10, the contribution of the near water table ( $\mathrm{Sr} \%)$ in the irrigation of the soil root zone may be predicted (Fig. 3). It was observed that the lowest values of $\mathrm{Sr} \%$ during the 2014-2015 growth season were recorded in May, June, and July 2015. The values of $\mathrm{Sr} \%$ were ranged between $12-16 \%$ for all soils under investigation. In August, 2015, the values ranged between 14-16\% for the El-Bghour, 
Berket El-Saba, and Talla areas, and reached 21\% for the Shebin El-Kom soil area. In March and April, 2015, the Sr\% values increased to $18-25 \%$. The highest values of the contribution of ground water $(\mathrm{Sr} \%)$ to root zone irrigation occurred in November and December 2014, and in January and February 2015, where the values were ranged from $25-41 \%$. The highest values of the contribution $(\mathrm{Sr} \%)$ during this growth period were in particular, in the Talla and Shebin El-Kom soil areas, where $\mathrm{Sr} \%=30-41 \%$. Generally, in winter the water table contributed $20-40 \%$ of irrigation water applied to the root zone and $20 \%$ or less during summer in the studied soils areas (Fig. 3). These results are in agreement with those obtained by Baehr and Reilly (2014) and Soppe and Ayars (2003). These variations in the contribution of ground water to root zone irrigation may be due to changes in ground water depth, capillary rise rate, evapotranspiration, plant growth types and growth period, pore size distribution, drain efficiency in the different locations studied and soil temperature.

\section{SUMMARY AND CONCLUSIONS:}

Equations based on the infiltration functions were applied to estimate the hydraulic conductivity $\mathrm{K}(\theta)$ and sorptivity (S). The contribution of the water table to the irrigation of the root zone was predicted in the cultivated soils of the Nile Delta. Five cultivated and non-cultivated clay soils were used for the application of the assumed equations. The values of hydraulic conductivity for rapidly drainable pores (macropores), $\mathrm{K}(\theta) \mathrm{RDP}$ were observed in the following order; Shebin ElKom (IV) $>$ ElBagour (1) > Berket Elsaba (II) $>$ Talla (III) > Ebshan (V). The highest values of Ks $\left(\mathrm{cm} \mathrm{h}^{-1}\right)$ were evident in the ElBagour soil (profile 1), while the lowest values were produced by the Ebshan clay soil (profile V). The predicted values of the hydraulic conductivities were reasonable and occurred in the normal ranges of the investigated soils. Water sorptivity was determined at the unsteady state (S) and at the steady state $\left(\mathrm{S}_{\mathrm{w}}\right)$ of infiltration. It was found that $\mathrm{S}$ decreased by $23.1 \%-45.7 \%$ in cultivated soils and by $55.2 \%$ in uncultivated soil, indicating that dry soils typically have a much greater sorptivity than wet soils. The steady $S_{w}$ parameter was used to predict the hydraulic conductivity $\mathrm{K}(\theta)$ and the basic (steady) infiltration rate $I_{b}$. The calculated values of $I_{b}$ corresponded to those obtained by the infiltration experiment. This confirmed the significance of steady $S_{w}$ as a new functional infiltration parameter. A matching factor $u$ was calculated as the ratio between the predicted $I_{\mathrm{b}}$ and the measured saturated Ks. In order to predict the contribution of the water table in moistening the root zone, the data of the water table depth, capillary rise, actual evapotranspiration (ETa), and crop factor parameters were obtained for 4 cultivated clay soil areas in the middle Nile Delta during 2014-2015 season. Using the relevant equations, it was found that in winter the water table contributed 
$20-40 \%$ of irrigation water applied to the root zone and $20 \%$ or less during the summer in the studied soils areas. This conclusion is important in calculating the crop water requirements and for irrigation scheduling.

Conflict of interest: The Author does not declare conflict of interest.

\section{REFERENCES}

Amer A.M., Logsdon S.D., Davis D., 2009. Prediction of hydraulic conductivity in unsaturated soils. Soil Sci., 174(9), 508-515, https://doi.org/10.1097/SS.0b013e3181b76c29

Amer A.M., 2002. Drainable and water-filled pores as related to water storage and conductivity in agricultural soils of the Nile Delta. Monash Univ., Melbourne, Australia, $28^{\text {th }}$ SIL Congress Proceedings, 1922-2010, Verh. Internat. Verein. Limnol., 2002, 28(4), 1912-1919. Stuttgart, https://doi.org/10.1080/03680770.2001.11901962

Amer A.M., 2004. Soil hydrophysics. $2^{\text {nd }}$ part, Agricultural irrigation and drainage (in Arabic). El-Dar Al-Arabia for Publish., Cairo, Egypt.

Amer A.M., 2009. Moisture adsorption capacity and surface area as deduced from vapour pressure isotherms in relation to hygroscopic water of soils. Biologia, 64(3), 516-521, https://doi. org/10.2478/s11756-009-0073-z

Amer A.M., 2010. Infiltration functions as applied to predict the hydraulic conductivity in matrix and macro pores of soils. 18th International Poster Day, Transport of Water, Chemicals and Energy in the Soil-Plant-Atmosphere System, Hydrology Institute, Bratislava.

Amer A.M., 2011. Effects of water infiltration and storage in cultivated soil on surface irrigation. Agric. Water Manage., 98(5),815-822, https://doi.org/10.1016/j.agwat.2010.12.006

Amer A.M., 2011. Prediction of hydraulic conductivity and sorptivity in soils at steady-state infiltration. Arch. Agron. Soil Sci., 58(10), 1179-1194, https://doi.org/10.1080/03650340.2011.572877

Amer A.M., 2012. Water flow and conductivity into capillary and non-capillary pores of soils. Journal of Soil Science and Plant Nutrition, 12(1), 99-112, https://doi.org/10.4067/ S0718-95162012000100009

Anat A., Duke H.R., Corey A.T., 1965. Steady upward flow from water tables. Colorado State Univ. Hydrol. Paper No. 7. June.

Ankeny M.D., 1992. Methods and theory for unconfined infiltration measurements. In Advances in measurement of soil physical properties: Bringing Theory into Practice (Ed. G.C. Topp, et al. ). SSSA Spec. Publ. 30. SSSA, Madison, WI, 123-141.

Baehr L. and Reilly J., 2014. Unsaturated flow characterization utilizing water content data collected within the capillary fringe. Air, Soil and Water Res., 7, 47-52, https://doi.org/10.4137/ASWR.S13282

Campbell G.S., 1974. A Simple method for determining unsaturated conductivity from moisture retention data. Soil Sci., 117(6), 311-314, https://doi.org/10.1097/00010694-197406000-00001

Dane J.H., Topp G.C. (eds), (2002). Methods of soil analysis, Part 4, Physical methods. SSSA, Madison, WI.

Encyclopedia, 1998. Encyclopedia hydrologic cycle - Image Results, Britannica, Inc.

Germann P.F., Prasuhn V., 2018. Viscous flow approach to rapid infiltration and drainage in a weighing lysimeter. Vadose Zone J., 17(1), 170020, https://doi.org/10.2136/vzj2017.01.0020

Hallett P.D., 2008. A brief overview of the causes, impacts and amelioration of soil water repellency a review. Soil \& Water Res., 3(1), S21-S29, https://doi.org/10.17221/1198-SWR

Hillel D., 1980. Fundamentals of soil physics. Academic Press, New York, https://doi.org/10.1016/ B978-0-08-091870-9.50006-6 
Jorenush M.H., Sepaskhah A.R., 2003. Modelling capillary rise and soil salinity for shallow saline water table under irrigated and non-irrigated conditions. Agr. Water Manage., 61, 125-141, https://doi.org/10.1016/S0378-3774(02)00176-2

Klute A., 1986. Methods of soil analysis. 2nd ed. ASA and SSSA, Madison.

Kostiakov A.N., 1932. On the dynamics of coefficient of water-percolation in soils and on necessity for studying it from a dynamic point of view for purposes of amelioration. Trans. $6^{\text {th }}$ Comm. Intern. Soil Sci., Russia, Part A, 17-21.

Lu N., Likos W.J., 2004. Rate of capillary rise in soil. J. Geotechnical and Environmental Eng., 130(6), 646-650, https://doi.org/10.1061/(ASCE)1090-0241(2004)130:6(646)

Malik R.S., Kumar S., Malik R.K., 1989. Maximal capillary rise flux as a function of height from the water table. Soil Sci., 148(5), 322-326, https://doi.org/10.1097/00010694-198911000-00002

Moldrup P., Hansen J.A.A., Rolston D.E., Yamaguchi T., 1993. Improved simulation of unsaturated soil hydraulic conductivity by the moving mean slope approach. Soil Sci.. 155, 8-14, https://doi. org/10.1097/00010694-199301000-00002

Page A.J., 1982. Methods of soil analysis. 2nd ed., Soc. Agron. Inc. Pub., Madison, Wisconsin.

Philip J.R., 1957. The theory of infiltration: 1. The infiltration equation and its solution. Soil Sci., 83, 345-357, https://doi.org/10.1097/00010694-195705000-00002

Ravina I., Zaslavsky D., 1968. Non-linear electro-kinetic phenomena I: review of literature. Soil Sci., 106(1), 60-66, https://doi.org/10.1097/00010694-196807000-00009

Reynolds W.D., Elrick D.E., Young E.G., 2002. Single-ring and double-ring or concentric-ring infiltrometers. 821-826. In Methods of soil analysis. Part 4 Physical methods (Eds J.H. Dane, G.C. Topp). SSSA, Madison, 821-826.

Soppe R.W., Ayars J.E., 2003. Characterizing ground water use by safflower using weighing lysimeters. Agr. Water Manage., 60(1), 59-71, https://doi.org/10.1016/S0378-3774(02)00149-X

Sparks D.L. (ed.), (1996). Methods of soil analysis, Part 3, Chemical methods. ASA, SSSA, Madison.

Sudnitsyn E.E., 1979. Soil water movement and water requirements of crops. Moscow Univ. Ezdat, Moscow.

Vadunina A.F., Karchagina, (1973). Investigation methods of soil physical properties and ground water. $2^{\text {nd }}$ ed. Vishaya Shcola, Moscow.

Valiantzas J.D., Pollalis E.D., Soulis K.X., Londra P.A., 2009. Modified form of the extended Kostiakov equation including various initial and boundary conditions. J. Irrig. Drain. Engin., 135(4), 450-458, https://doi.org/10.1061/(ASCE)IR.1943-4774.0000011

Weiler M., 2017. Macro-pores and preferential flow - a love-hate relationship. Hydrology Process., 31, 15-19, https://doi.org/10.1002/hyp.11074 